\title{
Decoupling Responsible Management Education - Why Business Schools May Not Walk Their Talk
}

\section{Abstract:}

Business schools increasingly aim to embed corporate responsibility, sustainability, and ethics into their curricular and extracurricular activities. This paper examines under what conditions business schools may decouple the structural effects of their engagement in responsible management education from organizational practices. We argue that schools may be unable to match rising institutional pressures to publicly commit to responsible management education with their internal capacity for change. Our analysis proposes that decoupling is likely if schools (1) are exposed to resource stringency, (2) face overt or covert resistance against change processes, (3) are confronted with competing institutional pressures, and (4) perceive institutional demands as ambiguous. The discussion points to two implications. While decoupling may give rise to the illusion that responsible management education is progressing, it is also possible that an inconsistency between talk and action can help schools to articulate ambitions for responsible management education, which, over time, inspire recoupling effects.

Keywords: responsible management education, decoupling, business schools, institutional theory, curriculum change 


\section{INTRODUCTION}

Calls for more responsible management education have increased in recent years (Holland, 2009; Samuelson, 2011). Driven by discussions about whether and to what extent business schools contributed to the 2008-2009 financial crisis (Currie, Knights, \& Starkey, 2010; Giacalone \& Wargo, 2009) and large-scale corporate accounting scandals (Klimek \& Wenell, 2011), the discourse on responsible management education has gained traction. Most importantly, we have witnessed the emergence of numerous initiatives that problematize "traditional" management education by calling on business schools to adapt to new realities. Initiatives like the UN-backed Principles for Responsible Management Education (PRME), the Globally Responsible Leadership Initiative (GRLI), and the Academy of Business in Society (ABIS) as well as accreditation agencies like the European Foundation for Management Development (EFMD) have called on business schools to embed relevant discussions into their curricula and extracurricular activities. Faced with public criticism and the need to differentiate program offerings in a competitive market environment, many business schools have committed to reform their practices (e.g. 520 schools have signed up to the PRME; as of December 2013).

This increasing interest in and institutionalization of responsible management education has given rise to a tension. On the one hand, corporate responsibility is no longer a fringe topic. It is widely discussed, both in the scholarly world as well as in the public sphere, and business schools have pledged to make progress in terms of embedding relevant discussions (Di Meglio, 2010). On the other hand, recent empirical assessments of schools' practices in this area have identified numerous obstacles that seem to inhibit in-depth change. Rasche, Gilbert, \& Schedel (2013) found that although business schools have added a lot of courses to their curricula, around $75 \%$ of these courses remain electives that are detached from core disciplines like finance and 
accounting. Solitander, Fougere, Sobczak, \& Herlin (2012) discussed strategic, structural and cultural barriers that need to be overcome when integrating relevant content into the curriculum (see also Young \& Nagpal, 2013). This tension between schools' increased public commitment towards responsible management education and the difficulties surrounding implementation remains largely unacknowledged and undertheorized.

Whereas existing scholarly work on responsible management education has increased our knowledge about changes to pedagogical methods (Shrivastava, 2010), course content (Kurland et. al, 2010) and curriculum design (Christensen, Peirce, Hartmann, Hoffmann, \& Carrier, 2007), we know surprisingly little about whether schools' commitment to responsible management education actually affects their core organizational practices. The aim of this paper is to theoretically debate in how far business schools can possibly translate this commitment into substantive implementation activities. Based on insights from organizational institutionalism, we argue that responsible management education increasingly exposes schools to institutional pressures that can hardly be neglected (e.g. due to changing accreditation criteria). We further argue that while schools may respond to these pressures by modifying some of their formal structures (e.g. introducing new policies), there is a risk that under certain conditions they will decouple these structures from implementation practices.

Our analysis explores these conditions and suggests that decoupling is likely to occur (1) when schools only have limited resources available, (2) there is resistance by influential organizational actors, (3) when schools face competing non-aligned institutional pressures, and (4) when organizational actors perceive institutional demands around responsible management education as ambiguous and hence believe that symbolic adoption will remain undiscovered. We discuss why decoupling is likely under these conditions by combining insights from 
organizational institutionalism (Zucker, 1987), the sociology of education (Coburn, 2004), and the scholarly debate around responsibility and ethics in management education (Swanson \& Fisher, 2008). It is important to note that we are not claiming that all business schools decouple talk from action when it comes to responsible management education. Research points out that organizations in the same institutional field respond in different ways to similar institutional pressures (Meyer \& Rowan, 1977), for instance because organizations vary in their need to appear rational and legitimate to outside audiences (Oliver, 1991). What we are claiming is that due to the particular organizational characteristics of business schools and the specific nature of institutional pressures surrounding responsible management education, there is a risk that some schools may decouple the structural effects of institutional demands.

We discuss the implications of our argument in two ways. On the one hand, decoupling can be seen as problematic, as it leads to the illusion that business schools integrate relevant debates into their curricular and extracurricular activities. Such an illusion can promote a certain degree of cynicism among students and faculty and also mislead impact assessments. On the other hand, schools' public communication of their ambitions can also produce positive organizational change, even if this talk is not yet matched with actions. This is because "aspirational talk" can potentially alter the perceptions of organizational actors, allowing them to discover new solutions and enabling changes of values, beliefs, and identities (Christensen et al., 2013). Such changes can help actors to rethink and redefine selected practices, particularly if the communicated aspirations create expectations by students or faculty members that cannot be ignored in the long run. This is not to claim that decoupling is a desirable state of affairs. Rather it shows that an inconsistency between schools' talk and action may over time initiate change. 
Our analysis proceeds as follows. Section two briefly introduces responsible management education as an institutionalized practice. Section three discusses the theoretical background of our argument, presenting relevant thoughts around organizational institutionalism and decoupling. Section four first shows in what ways business schools have been exposed to rising institutional pressures to adopt responsible management education, and then discusses the conditions under which schools may respond to these pressures by decoupling formal structures from core organizational activities. While the fifth section outlines the implications of our argument, the final section concludes with an agenda for future empirical research.

\section{RESPONSIBLE MANAGEMENT EDUCATION}

We use the term responsible management education as a descriptor for efforts aimed at embedding corporate responsibility, sustainability and ethics into business schools' organizational practices (Godeman, Haertle, Herzig, \& Moon, 2013; Forray \& Leigh, 2012). These practices are not limited to modifying the curriculum, but also include changes of research practices, pedagogies, overall organizational strategies, as well as extracurricular activities. It is important to point out that the key motivation behind responsible management education is to integrate relevant discussions into business schools, moving beyond a situation in which the topic is treated as an add-on. For instance, the PRME (2013a) initiative recognizes that "in the current academic environment corporate responsibility and sustainability have entered but not yet become embedded into the mainstream of business-related education." Responsible management education aims to "normalize" the discussion of social, environmental and ethical issues within business schools, for instance by moving relevant topics into courses that have traditionally not addressed these debates (e.g. accounting and finance). 
Integrating responsibility, sustainability, and ethics into business schools seems both important and timely. On the one hand, an isolated treatment is unlikely to have much of a lasting impact on students' learning experiences. Integration helps to contextualize issues and also signals importance (Dunfee \& Robertson, 1988). On the other hand, research shows that most discussions are currently either tied to specifically designed standalone courses (Christensen et al., 2007), which are rarely part of the core curriculum (Navarro, 2008), or are embedded in management-related disciplines. Nicholson and DeMoss (2009) found that accounting and finance department coordinators attached much less importance to corporate responsibility than did management and marketing coordinators, while a survey by Hansen, Moosmeyer, Bode, \& Schrader (2007) revealed that academics with a background in accounting and finance attached the least relevance to responsible management, while scholars with a background in human resource management attached the highest.

Of course, the need to integrate relevant topics into business schools' practices has been a long-standing concern (see e.g. Starik, Rands, Marcus, \& Clark, 2010 for a review). However, the creation of coalitions - like the GRLI, ABIS and the PRME - as well as the increasing support by accreditation agencies and student organizations has helped to institutionalize responsible management education, making it commonly accepted behaviour and hence hard to ignore for business schools. This institutionalization is also backed by corporations who themselves face pressures to commit to and report on responsible business practices (Etzion \& Ferraro, 2010). For instance, the PRME emerged from a desire to reform management education voiced by business leaders participating in the UN Global Compact (Waddock, Rasche, Werhane, \& Unruh, 2011). 
While our knowledge about responsible management education has increased, most contributions are focused on describing the current state of curriculum change (e.g. Christensen et al., 2007; Navarro, 2008; Wu, Huang, Kuo, \& Wu, 2010), necessary reforms of pedagogical methods (Shrivastava, 2010), and changes to course content (Kurland et al., 2010). Surprisingly little scholarly debate focuses on the organizational context surrounding the implementation of responsible management education (for a recent exception see Blasco, 2012). This paper focuses on this context and develops a critical analysis of those conditions that potentially lead to a decoupling of the structural effects of responsible management education from organizational practices.

\section{DECOUPLING AND ORGANIZATIONAL INSTITUTIONALISM}

\section{Organizational Institutionalism}

Theoretical debates around decoupling emerged as part of conceptual and empirical work on organizational institutionalism (Boxenbaum \& Jonsson, 2008). The main thesis underlying institutional theory is that organizations are affected by the institutional context in which they operate. This context consists of "common understandings of what is appropriate and, fundamentally, meaningful behavior" (Zucker, 1983: 105) and defines what is considered as rational conduct. Institutionalized practices within this context reflect widely accepted behaviour that is underpinned by certain normative and cognitive understandings. The resulting institutional pressures influence organizational practices, because organizations conform to this rationalized context in order to appear legitimate (Scott, 1995). Conformity to institutional pressures creates isomorphic behaviour among organizations - i.e. organizations become more alike, since institutionalized practices are diffused throughout space and time. Institutional theorists suggest 
three mechanisms of isomorphic change (DiMaggio \& Powell, 1983): (1) coercive isomorphism (practices are adopted to avoid sanctions), (2) mimetic isomorphism (practices are adopted to imitate successful peers), and (3) normative isomorphism (practices are adopt because it is the right thing to do).

Organizations whose behaviour is guided by institutionalized practices can be thought of as belonging to a common organizational field. Scott (1995: 56) defines such fields as "a community of organizations that partakes of a common meaning system and whose participants interact more frequently and fatefully with one another than with actors outside the field." This definition emphasizes the relational component of fields - i.e. fields (and the institutional demands that are embedded in them) are created in and through the interactions of organizations that together form a recognized area of institutional life (DiMaggio \& Powell, 1983). Hoffman (1999: 352) emphasizes that fields also act as platforms for discussions around a common theme - "the field should be thought of as the center of common channels of dialogue and discussion [...] which bring together various field constituents with disparate purposes."

Following Hoffman's (1999) understanding, we can think of responsible management education as being part of the larger organizational field of management education. This field consists of a community of organizations, which, even though they may have different purposes, interact around a common theme. Relevant actors in this field include: business schools, accreditation agencies (e.g. AACSB), governmental regulators, student organizations (e.g. Net Impact), providers of rankings (e.g. the Financial Times), and professional networks (e.g. the GRLI). Although the network of relationships in this field structures schools' actions, the field also contains a variety of competing and even contradictory institutional pressures. For instance, while international rankings specify certain measures around which schools can be compared, 
responding to these measures can neglect other demands that are put on business schools (Wedlin, 2007).

\section{Decoupling - The Symbolic Adoption of Formal Structure}

Conformity to external institutional pressures can contradict organizations' internal requirements. In these cases, organizations' conformity with institutional pressures may only be ceremonial - i.e. they decouple the formal structures that are adopted to conform to institutional demands from their day-to-day activities (Meyer \& Rowan, 1977). As organizations need to appear legitimate and rational (to gain social approval and to secure their survival), they deploy such legitimating structures to meet institutional demands, but disconnect these structures from core organizational practices (Oliver, 1991; Scott, 1995). In other words, organizations' formal structure (e.g. official policies, programs, positions, and procedures) and the language ("talk") that is used to describe these structures have largely a symbolic function.

Empirical evidence for decoupling comes from different studies covering a variety of organizational contexts. Maclean and Behnam (2010), for instance, showed how an organization created positive legitimacy perceptions by symbolically adopting a compliance program. Westphal, Gulati, \& Shortell (1997) discussed how organizations gained legitimacy from symbolically adopting total quality management (TQM), while Edelman, Petterson, Chambliss, \& Erlanger (1991) demonstrated how an organization created visible symbols of compliance around institutional demands for affirmative action without changing its practices. Together, these studies give substance to Meyer and Rowan's (1977) original proposition that external audiences are willing to grant legitimacy based on symbolic responses to institutional demands. Decoupling can help to get management support for decisions on reform, since it acts as a 
mechanism that buffers internal routines, which have developed over time, from growing institutional demands (Brunsson \& Olsen, 1993). This enhances the flexibility of the organization, while maintaining legitimacy with selected external constituents. This paper suggests that reforms promoted through responsible management education risk to be affected by such decoupling behaviour.

\section{RESPONSIBLE MANAGEMENT EDUCATION AND THE RISK OF DECOUPLING}

We first argue that business schools are exposed to a variety of institutional pressures to adopt responsible management education. Based on this, we outline four conditions under which it is likely that schools respond to such pressures by decoupling the structural effects of institutional demands from actual implementation practices.

\section{Institutional Pressures for Responsible Management Education}

We conceive of responsible management education as an emerging institutional context. This context defines what is commonly considered to be appropriate behaviour (i.e. embedding responsible business into management education) and consists of various institutionalized practices (e.g. curriculum change and the adoption of new pedagogical practices). Although responsible management education may not be fully institutionalized yet, it is clear that schools cannot simply ignore the emergence of these institutional demands, particularly if they want to be seen as legitimate actors. We refer to DiMaggio and Powell's (1983) discussion of coercive, mimetic and normative mechanisms of isomorphic change to understand in what ways schools are exposed to institutional pressures. 
Coercive Pressures. Some organizations exert coercive pressures on business schools to embed responsible management education, implying that a full neglect of relevant practices would result in some form of sanction. Accreditation agencies can be considered as one important source of coercive pressure in the context of higher education (Caravella, 2011). For instance, although AACSB does not prescribe specific courses, the latest accreditation criteria list ethics and social responsibility as an area in which the development of skills is required (AACSB, 2013: 30). The criteria also outline that schools have to adopt policies and procedures to support and enforce ethical behaviour by students, faculty and administrators (AACSB, 2013: 5). The most recent EQUIS accreditation guidelines even devote an entire chapter to responsible management education.

The School should have a clear understanding of its role as a "globally responsible citizen" and its contribution to ethics and sustainability. This understanding should be reflected in the School's mission, strategy and activities. There should be evidence that the School's contribution is reflected in its regular activities, covering education, research, interactions with businesses and managers, community outreach and its own operations. (EFMD, 2013: 64)

EQUIS requires a separate strategy on responsible management education "listing the School's formal commitments to ethics, responsibility, and sustainability (e.g. U.N. PRME).” (EFMD, 2013: 65) The Association of MBAs (AMBA) criteria for the accreditation of MBA programs also demand that students achieve a "significant understanding of the impact of sustainability, ethics and risk management on business decision and performance.” (AMBA, 2013: 7) Although accreditation criteria are usually written in a flexible way, schools cannot fully ignore these expectations, especially since accreditations act as an important source of legitimacy (Durand \& 
McGuire, 2005) and relevant agencies have created a degree of dependence on the side of business schools (Wilson \& McKiernan, 2011).

Mimetic Pressures. Business schools also face mimetic pressures around responsible management education - i.e. they model their commitment on what other influential schools have done in this area. Uncertainty is a key driver of such mimetic behaviour. As responsible management education remains a rather vague concept, schools model their commitment on what other well-recognized players have done. For instance, prestigious schools like INSEAD and the London Business School were among the first signatories of the PRME. This legitimized the underlying agenda and made it attractive to new adopters. Further, media coverage of curriculum updates at major business schools can give other schools the feeling that "doing nothing" may turn them into a bystander or even outlier. For instance, Columbia Business School's integration of ethics and responsible leadership was featured in The Wall Street Journal (Korn, 2011), while Bloomberg Businessweek discussed Wharton's move towards embedding responsibility deeper into its revamped MBA program (Damast, 2010). Participant differentiation within relevant associations can also stimulate mimetic tendencies. The PRME, for instance, established a "Champions Group", consisting of 31 signatory schools that are believed to be leaders when it comes to responsible management education (PRME, 2013). As these schools are perceived as role models, it can be expected that other schools will look at them as a source of inspiration.

Normative Pressures. A third source of institutional pressure is normative (Suchman, $1995)$ - i.e. responsible management education is widely considered to reflect a proper course of action. Business schools' organizational environment has signalled in different ways that integrating ethics and responsibility into curricula is "the right thing to do". Three sources of normative pressure are particularly noteworthy. First, student organizations like Net Impact have 
acted as public advocates, arguing that schools are not doing enough to fully embed relevant topics. Judgments about the appropriateness of reforms are framed as being aligned with the value system of the majority of students (Net Impact, 2009). Second, publications in trusted media outlets have called on schools to change their educational frameworks, often emphasizing the normative nature of reforms. Cossin (2011), for instance, argued in the Financial Times that business school education has "misled a generation of managers" and that by ignoring reforms schools "run the risk of fatally damaging their credibility." Finally, professional networks like the GRLI or the PRME develop norms that define what counts as desirable behaviour. Faculty champions from different schools are organized in such networks. These champions carry these norms back into their organizations and try to act upon them (see the cases discussed by Solitander et al., 2011).

\section{Responsible Management Education and the Risk of Symbolic Adoption}

Many business schools have responded to these pressures by redesigning elements of their formal structure, demonstrating that they adhere to newly emerging expectations. Examples of such structural elements include, but are not limited to: policies that frame a school's commitment and engagement, formalized programs (e.g. for curriculum change), and new governance structures (e.g. faculty committees). These structural elements are often reflected in the "talk" that business schools produce around responsible management education (e.g. on websites and in public reports; see Godemann et al., 2013; Godemann, Herzig, Moon, \& Powell 2011). We argue that there is a risk that under certain conditions schools may decouple these structural effects from their core organizational practices. Two of these conditions (i.e. resource stringency and resistance) relate to the organizational characteristics of business schools, while 
the other two conditions (i.e. competing and ambiguous institutional demands) relate to the organizational field in which schools are embedded.

Decoupling as a response to resource stringency. Based on Meyer and Rowan's (1977) seminal work, research has argued that decoupling occurs because of a perceived conflict between institutional pressures and internal efficiency demands (Westphal \& Zajac, 1998). This perspective holds some relevance in the context of our argument. Although responsible management education as such does not make schools more or less efficient, substantive implementation requires resources that can cause a conflict between institutional pressures and resource availability. Making changes to existing courses or adding new courses demands time (e.g. to assess and redesign the curriculum) and expertise (e.g. in terms of developing faculty), both of which involve financial and non-financial resource commitments (Swanson \& Fisher, 2008). Of course, the costs associated with relevant change processes depend on the scale, scope and time horizon of the process itself. While the costs of "quick fixes", like adding an elective to an existing program, may be limited, the costs of substantive cross-disciplinary integration of responsible management education across courses and programs can expected to be high (e.g. because such a process requires more active steering through faculty committees; see e.g. Young and Nagpal, 2013).

Faced with a tightening of government funds and increased competition for third party funding, many business schools have to cover these implementation costs in a challenging financial environment. Governments have reduced funding for higher education on a per student basis in a number of countries, since there is tight competition for societal financial resources (Fethke \& Policano, 2013; Peters \& Thomas, 2011). Although alternative funding models are emerging (e.g. tuition fees and executive education), at least some schools are likely to have 
problems to bear the full cost of integrating responsible management education, especially when considering that the development of curricular and extracurricular activities is an on-going task and not a one-off activity. Schools may try to resolve this tension between resource stringency and institutional pressures by symbolically adopting responsible management education for legitimacy purposes.

Decoupling as a response to resistance. Prior research has emphasized that the existence of power dynamics can stimulate decoupling behaviour. Westphal and Zajac (2001) found that organizations decoupled formal structures from core activities when influential actors had no interest in implementation. Such power dynamics are likely to influence whether business schools symbolically adopt relevant structural elements. Although the majority of deans publicly support responsible management education (Evans \& Weiss, 2008), their influence on the curriculum remains limited. The faculty-governed nature of business schools (Mortimer \& Sathre, 2010), the importance ascribed to the concept of "academic freedom" (Gross-Schaefer, 2010), and the inertia created by the tenure system (Dowd \& Kaplan, 2005) are structural features that limit deans' influence on the curriculum. For instance, the tenure system can act as an obstacle to change, as tenured faculty face little pressure to rework course materials (Murray, 2013). Few professors want to be told by others what and how they are supposed to teach, especially when considering that courses are already packed with content that teachers perceive as important (Alsop, 2006).

When trying to integrate responsible management into courses and programs, business schools depend on a change model in which actors themselves have to see the need for change and act in reflexive ways (Antonacopoulou, 2010). However, such change is hard to implement due to existing prejudices. Claims like responsible management cannot be taught and that 
teaching such topics has no lasting impact remain widespread. Evans \& Weiss' (2008) research showed that $34 \%$ of deans identified faculty resistance as an obstacle to further integrate discussions around corporate responsibility into the curriculum. Beggs \& Dean (2007) concluded from an interview study that most faculty members did not believe that teaching responsibility and ethics would help to avoid situations like the series of corporate accounting scandals in 2000/2001. Another study showed that faculty members often resist change because they believe that relevant discussions are sufficiently covered elsewhere in the curriculum (Dean \& Beggs, 2006). Avoiding integration can thus serve the function of minimizing disputes and conflicts among faculty members.

Even if there is no open resistance towards curriculum change, faculty can still oppose unwanted adjustments in more covert ways. Discussions around curriculum change usually focus on changing syllabi and the composition of courses in a program, mostly because such changes can be documented and reported (Godemann et al., 2011). However, contributions to the sociology of education have highlighted that teachers can sometimes afford to disregard such changes, leaving their existing classroom practices unaffected (McLaughlin \& Talbert, 2001). For instance, Coburn (2004) found that teachers assessed changes in instructional policies through the lens of their own pre-existing beliefs and practices and, based on this, decided whether to implement them in practice. As academics enjoy a high degree of freedom (e.g. due to tenure policies) and since enforcing compliance with curriculum change via control mechanisms is neither desirable nor enforceable, such covert resistance can encourage decoupling as a response strategy.

Decoupling as a response to multiple field-level pressures. Decoupling may not only be driven by certain organizational features of business schools, but also by the characteristics of the 
organizational field in which institutional pressures are embedded. Studies have shown that organizations symbolically adopt formal structures when fields contain multiple institutional pressures (Ruef \& Scott, 1998). Organizations respond to such pressures by conforming to some selected demands via substantive implementation, while decoupling the structural effects of other demands. The embeddedness of responsible management education into the field of management education exposes schools to such multiple pressures, making it hard to simultaneously respond to all institutionalized requirements.

While some actors put pressure on schools to buy into responsible management education, other actors do not acknowledge this agenda. The case of business school rankings (e.g. by the Financial Times) is particularly interesting. Although the demands created by ranking criteria do not contradict responsible management education, none of the widely acknowledged rankings contain explicit criteria for schools' performance in this area. This is likely to create a situation in which rankings and the integration of responsibility into the curriculum compete for scarce resources. Playing "the ranking game" (Corley \& Gioia, 2000) often requires investments, especially in those areas highlighted by the underlying criteria (e.g. the Financial Times ranking is largely based on salary percentage increase, creating incentives to invest in placement services). Because the reputational effects of rankings are significant (Wedlin, 2007), schools with limited resources may strategically decide to invest only in responding to those institutional pressures that have the highest effect on their perceived legitimacy. Although specialized rankings like the "Global Green MBA" exist, their effects on a school's overall reputation remain limited, as organizations' reactivity to rankings depends on the latter's dissemination and perceived credibility (Espeland \& Sauder, 2007). 
Decoupling as a response to perceived ambiguous institutional demands. Organizations symbolically adopt structures if the institutional demands they are facing are perceived as ambiguous. Edelman (1992: 1532), for instance, found that "broad and ambiguous principles [...] give organizations wide latitude to construct the meaning of compliance." Her analysis of the adoption of affirmative action policies showed that the ambiguity of the underlying rules motivated organizations to implement policies in ways that are minimally disruptive to the status quo. If institutional demands are framed through ambiguous language, adopters miss distinct guidance on implementation and retain a high degree of interpretive flexibility (George, Chattapadhyay, Sitkin, \& Barden, 2006). This flexibility can be used in different ways. While some organizations will use it to adapt implementation processes to their own context (especially in cases where change is perceived to drive competitiveness), other organizations will use this flexibility to decouple their formal structures.

The institutional pressures originating from responsible management education contain a high level of ambiguity and hence may be perceived as vague by those in charge of implementation. For instance, schools signing up to the PRME commit to creating "educational frameworks, materials, processes and environments that enable effective learning experiences for responsible leadership" and developing "the capabilities of students to be future generators of sustainable value for business and society at large and to work for an inclusive and sustainable global economy." (PRME, 2013b) While the PRME has highlighted that this vagueness is deliberate, as the initiative does not regulate schools' activities, it is also clear that signatories can hide inaction behind such general requirements. Interestingly, schools seem to react to such ambiguous requirements with ambiguity. An assessment of the Sharing Information on Progress 
(SIP) reports, which is required from PRME signatories, revealed that "many reports appear to be rather vague in specifying their educational framework.” (Godemann et al., 2011:23)

Accreditation agencies have similar vague requirements. For instance, AACSB (2013) states that in the context of responsible management education "there is nothing in the standards that requires particular courses or treatments. Schools should assume great flexibility in fashioning curricula to meet their missions and to fit with the specific circumstances of particular programs." Although this flexible approach is consistent with AACSB's general strategy of mission-driven accreditation (Romero, 2008), it also opens the door for approaches to responsible management education that remain limited in scope and scale. The ambiguous nature of institutional demands makes schools' "talk" around responsible management education relatively cheap - i.e. it is possible to make rather broad public commitments but hide limited action or even inaction behind general requirements and language. As a school's progress is judged through weak accountability mechanisms (e.g. self-reported communications in the context of the PRME), there is only a minimal risk that inaction may be exposed.

Each of the four conditions frames a specific context in which it is more likely to find decoupling. This is not to say that business schools will always decouple under these conditions. A lot depends on how an organization frames responsible management education in its own context. For instance, schools who see a change in educational practices as being aligned with their values (e.g. when having a religious affiliation; Evans et al., 2006) may engage in substantive implementation despite the existence of the discussed conditions. 


\section{IMPLICATIONS OF DECOUPLING RESPONSIBLE MANAGEMENT EDUCATION}

Our analysis suggests that there is a risk that business schools may decouple the structural effects of responsible management education from core organizational practices. What, then, are the implications of this identified risk? On the one hand, decoupling may lead to the illusion that business schools are integrating responsible management education. On the other hand, it can be argued that an inconsistency between talk and action can help schools to articulate ambitions for responsible management education, which, in turn, can stimulate long-term change processes.

\section{The Dangers of Decoupling - The Illusion of Integration}

One implication resulting from the decoupling proposition is that we may have the false impression that responsible management education is becoming mainstreamed into curricular and extracurricular activities. Faced with an increasing number of schools signing up to initiatives in this area and adopting relevant policies, we are inclined to believe that change is under way. However, the mere fact that more schools publicly express their commitment does not say much about whether relevant debates are really integrated into business schools' practices. We risk confusing a growing public discourse around responsible management education and the establishment of organizational policies with greater impact. This lack of impact is at least partly confirmed by recent empirical work.

Godemann et al.'s (2011) assessment of the mandatory communications of PRME signatories showed that, while schools were publicly committed to making changes and also

picked some of the "low hanging fruits" (e.g. by creating new courses), few reflected on how to integrate relevant debates into their existing organizational practices. Not much different, Rasche 
et al. (2013) found that even though the overall number of courses with relevant content has been increasing, the vast majority of courses are electives that remain detached from disciplines like accounting and finance. The strategy of adding electives to existing programmes may be a response to some of the conditions discussed above. Creating new elective courses is likely to face less resistance by faculty, as a program's established core curriculum remains unchanged. Also, electives are usually cheaper to run, as fewer students participate (e.g. lowering assessment costs). However, electives are unlikely to support integration, as such courses suffer from a selfselection bias. Electives are usually chosen by those students who already have a high interest in a given topic area (Bell, Connerley, \& Cocchiara, 2009). While creating mandatory courses can also have drawbacks (e.g. less motivated students), true integration can only be achieved when moving the discussion beyond isolated elective courses.

We may also misjudge the impact of schools' public commitment to responsible management education, because current assessments are too much focused on changes to the formal curriculum. But impact may also be undermined because what is implicitly included in educational experiences may carry messages that are inconsistent with what is formally taught in the classroom. Blasco (2012) calls this implicit dimension the "hidden curriculum"; it covers those practices that send tacit messages to students about what counts as responsible conduct (see also Sambell \& McDowell, 1998). Schools often send implicit messages about responsible conduct by endorsing or collaborating with certain firms, by "living" responsibility through their own practices (e.g. offering Fairtrade products), by asking students during course evaluations to reflect on whether a course has discussed responsibility issues (Blasco, 2012). Integrating responsible management education implies to establish organizational practices that align the messages send through the formal curriculum with those messages send through the hidden 
curriculum. As most schools seem to implement their commitment to responsible management education by adding/revising courses (see above), the role of the hidden curriculum is likely to be neglected, reinforcing the illusion that responsible management education is being integrated.

\section{Recoupling - Responsible Management Education as Aspirational Talk}

While decoupling can be perceived as dysfunctional, it is also possible to argue that the expression of high ambitions for responsible management education can stimulate organizational change and, in the long run, lead to improvements, even when such ambitions are not yet fully reflected in organizational practices. Christensen, Morsing, \& Thyssen (2013) have outlined this argument with regard to firms' corporate social responsibility (CSR) policies. They suggest that firms' CSR communication is often aspirational (i.e. not a perfect reflection of what they actually do). While this can lead to sustained decoupling, it is also possible that the talk about such aspirations helps to articulate values, beliefs, identities, and frameworks for decision-making, which then become embedded into the organization. This is not to say that firms (or business schools) emerge as responsible actors simply by articulating their aspirations. However, it is to say that the expression of high ambitions can help firms to explore what kind of organization they want to become and can inspire people to enact relevant change processes.

Theoretically speaking, this argument rests on a different understanding of the relationship between communication and action. While it is often assumed that communication and action are distinct entities (i.e. action follows communication when "walking the talk"), the view advocated here assumes that communication is action (i.e. language has performative effects and can, to a certain degree, shape reality; see Searle, 1969; Weick, 1979). Understood in this way, talk about an organization's commitments can have consequences for how the organization understands 
itself and its environment and may, under certain conditions (see below), lead to substantive changes in organizational practices.

Viewing schools' commitment to responsible management education as "aspirational talk" puts a different perspective on decoupling. A mismatch between the structures adopted to show commitment to responsible management education and relevant organizational practices may only reflect a temporary state of affairs. As schools talk about these structures (e.g. their policies and change initiatives etc.) and thereby express their ambitions, they articulate a desired future for the organization. Such articulations can initiate incremental change processes, slowly altering behavioural expectations and the identity of the school. These effects, in turn, can alter some of the underlying conditions for decoupling (e.g. the importance ascribed to competing institutional demands may change). Hence, a schools' talk about its aspirations can lead to recoupling effects, even when this talk does not match organizational practices at the time when the aspirations were articulated.

Even though it is likely that schools' aspirational talk has a certain potential to initiate recoupling effects, we cannot assume that such effects will automatically occur once a school starts talking about its ambitions. When a school engages in aspirational talk to deliberately mislead its stakeholders (e.g. when lying about its true intentions), it is unlikely that visionary and aspirational talk initiates social change. In such cases, people are more likely to react with cynicism and negative legitimacy perceptions (Maclean \& Behnam, 2010). But, if a school engages in aspirational talk to communicate a wished-for-future, recoupling can occur, as the performative effects of talk are more likely to unfold (e.g. because actors are motivated). Although both types of aspirational talk are hard to distinguish in practice and a matter of empirical analysis, they need to be differentiated. 
The emergence of recoupling effects also depends on the context in which aspirations are expressed (Christensen et al., 2013; Taylor \& Cooren, 1997). For instance, aspirations stated during a public speech by the dean are more likely to have performative effects, as the public nature of such expressions and the social status of a dean create expectations by different stakeholder groups (e.g. students, alumni, faculty). Research shows that such public expressions of ambitions can foster change processes, as organizational members start to rethink their own role in the organization and their underlying values and beliefs (Haack, Schoeneborn, \& Wickert, 2012; Fiss and Zajac, 2006). Of course, it is difficult to predict specific outcomes and there is no guarantee that publically expressed aspirations about responsible management education become embedded in organizational practices. However, as schools' talk about responsible management is public (e.g. expressed in publicly available PRME reports or also on their websites), there is good reason to believe that a continuous mismatch between aspirational talk and organizational practices may be hard to sustain in the long run.

\section{CONCLUSIONS AND FURTHER RESEARCH}

This article suggests that there is a risk that business schools decouple the formal structures, which they are developing around responsible management education, from their core organizational practices. Our analysis shows (a) that schools are increasingly exposed to coercive, mimetic and normative institutional pressures to adopt relevant structures and (b) that that under certain conditions schools are likely to decouple these structures from implementation activities. Such reflections are important and timely. Discussing whether schools walk their talk helps us to better understand the necessary conditions for changing educational practices. While there is often widespread agreement that we need more responsible management education (Kell 
\& Haertle, 2011), much less is known about the conditions under which business schools are becoming engaged in implementation activities.

We neither argue against responsible management education nor do we question the relevance of the work that has been undertaken in this area (see e.g. Perry \& Win, 2013 and Young \& Nagpal, 2013). There are clearly cases where schools have successfully integrated responsible management education into their practices (see Solitander et al., 2011). Our arguments should be understood as an attempt to better understand and theoretically frame the limits of managing for responsible management education. Business schools can actively manage these limits, as institutional pressures do not completely determine the way responsible management education is managed. Actors within business schools have a degree of strategic choice (Wilson \& McKiernan, 2011). Many of these choices become visible when thinking about what can prevent decoupling or at least make it less likely. Our analysis shows that decoupling can be avoided if implementation is backed up with sufficient resources, if powerful and committed actors support implementation, if responsible management education is given high priority in light of competing institutional demands, and if ambiguous demands are specified. However, preventing decoupling presupposes that organizational actors are willing and able to make such choices in the first place. While some schools have demonstrated that such choices can be made (see e.g. the cases presented by Solitander et al., 2011), our arguments emphasize that there is a risk that other schools may focus too much on maintaining legitimating structures around responsible management education while protecting established organizational practices.

Our analysis shows the need to conduct further research in this area. First, the theoretical proposition presented in this paper needs to be supported or rejected by empirical research. In an ideal case, such research would compare data on how responsible management education shapes 
schools' structural elements (e.g. the policies, programmes, governance structures) with data on those organizational practices that are important for the integration of responsible management education (e.g. changes to curriculum design, pedagogical practices, assessment practices). Although it is alluring to use syllabi to observe changes to course content (see e.g. Rasche et al., 2013), in-depth qualitative data (e.g. via observations) may be better suited, as prior research has emphasized that teachers enjoy high degrees of autonomy when acting in the classroom (McLaughlin \& Talbert, 2001). Research would also need to consider the role of the "hidden curriculum" (see above), as the implicit messages that a school sends to its students may be as important as the more visible explicit changes.

Second, future research needs to look into the four observed conditions for decoupling. Empirical research has to test the relevance of these conditions and also discuss what mediates a school's engagement in decoupling under these conditions. The interaction among different conditions seems to be particularly interesting. For instance, the existence of competing institutional demands combined with resource stringency may increase the likelihood of decoupling. Conceptual research can discuss the relevance of other conditions. While we identified two organizational variables (i.e. resource stringency and resistance) and two fieldlevel variables (competing and ambiguous demands), there is no need to believe that this is a conclusive list. For instance, decoupling can also result from an organization's desire to create a powerful brand image (Elsbach \& Sutton, 1992). As many business schools operate in a highly competitive market environment, the development of a distinct brand image seems to increase in importance (Pitt, Berthon, Spyropoulou, \& Page, 2006). Such reflections could be meaningfully combined with field-level analysis. Schools with a central position in the field face higher risks 
when engaging in decoupling (as they are subject to public scrutiny), while peripheral actors can be expected to face less risk.

Third, our discussion frames decoupling as an either/or decision. However, the avoidance of institutional pressures is just one possible response strategy (Oliver, 1991), and business schools may decide to balance different institutional pressures by partially responding to all of them. Practically speaking, it is likely that schools decouple selected parts of their commitment to responsible management education (e.g. promoting extracurricular activities but neglecting curriculum reform), emphasizing those parts were changes to organizational practices can be achieved without much difficulty. Future research needs to explore whether such selective decoupling exists and, if so, what predicts whether specific elements of a school's structure are translated into its practices. 


\section{REFERENCES}

AACSB. 2013. Ethics and Sustainability Resource Center. Retrieved from: http://www.aacsb.edu/resources/ethics-sustainability/faq.asp (accessed 1 November 2013).

AMBA. 2013. Criteria for the Accreditation of MBA Programmes. AMBA: London.

Alsop, R. J. 2006. Business Ethics Education in Business Schools: A Commentary. Journal of Management Education, 30(1): 11-14.

Antonacopoulou, E. P. 2010. Making the Business School More "Critical": Reflexive Critique Based on Phronesis as a Foundation for Impact. British Journal of Management, 21, s6s25.

Beggs, J. M., \& Dean, K. L. 2007. Legislated ethics or ethics education? Faculty views in the post-Enron era. Journal of Business Ethics, 71: 15-37.

Bell, M. P., Connerley, M. L., \& Cocchiara, F. K. 2009. The case for mandatory diversity education. Academy of Management Learning and Education, 8: 597-609.

Blasco, M. 2012. Aligning the Hidden Curriculum of Management Education With PRME: An Inquiry-Based Framework. Journal of Management Education, 36(3): 364-388.

Boxenbaum, E., \& Jonsson, S. 2008. Isomorphism, Diffusion and Decoupling. In R. Greenwood, C. Oliver, K. Sahlin, \& R. Suddaby (Eds). The SAGE Handbook of Organizational Institutionalism: 78-98. London: Sage.

Brunsson, N. and Olsen, J.P. 1993. The Reforming Organization. London and New York: Routledge.

Caravella, K.D. 2011. Mimetic, Coercive, and Normative Influences in Institutionalization of Organizational Practices: The Case of Distance Learning in Higher Education. Doctoral Dissertation. Florida Atlantic University.

Cossin, D. 2011. Financial models create a false sense of security. Retrieved from http://www.ft.com/cms/s/2/af6d86de-d57a-11e0-9133-00144feab49a.html\# axzz1X26L82fF (accessed 28 November 2013).

Coburn, C. E. 2004. Beyond Decoupling: Rethinking the Relationship between the Institutional Environment and the Classroom. Sociology of Education, 77(3): 211-244.

Corley, K., and Gioia, D. 2000. The Rankings Game: Managing Business School Reputation, Corporate Reputation Review, 3: 319-333. 
Currie, G., Knights, D., \& Starkey, K. 2010. Introduction: A Post-crisis Critical Reflection on Business Schools. British Journal of Management, 21, s1-s5.

Christensen, L. T., Morsing, M., \& Thyssen, O. 2013. CSR as Aspirational Talk. Organization, 20(3): 372-393.

Christensen, L. J., Peirce, E., Hartman, L. P., Hoffman, W. M., \& Carrier, J. 2007. Ethics, CSR, and sustainability in the Financial Times Top 50 global business schools. Journal of Business Ethics, 73: 347-368.

Damast, A. 2010. Wharton Faculty Backs Curriculum Overhaul. Retrieved from: http://www.businessweek.com/bschools/content/dec2010/bs2010123_828086.htm (accessed 24 October 2013).

Dean, K. L., \& Beggs, J. M. 2006. University professors and teaching ethics: Conceptualizations and expectations. Journal of Management Education, 30: 15-44.

DiMaggio, P. J., \& Powell, W.W. 1983. The Iron Cage Revisited: Institutional Isomorphism and Collective Rationality in Organizational Fields. American Sociological Review, 48(2), $147-160$.

Di Meglio, F. 2010. The MBA marketing machine. Retrieved from: http://www.businessweek.com/bschools/content/jun2010/bs20100614_351 327.htm (accessed 15 August 2013).

Dowd, K. O., \& Kaplan, D. M. 2005. The career life of academics: Boundaried or boundaryless? Human Relations, 58(6), 699-721.

Dunfee, T. W., \& Robertson, D. C. 1988. Integrating Ethics into the Business School Curriculum. Journal of Business Ethics, 7(11): 847-859.

Durand, R., \& McGuire, J. 2005. Legitimating Agencies in the Face of Selection: The Case of AACSB. Organization Studies, 26(2): 165-196.

Edelman, L. B. 1992. Legal Ambiguity and Symbolic Structures: Organizational Mediation of Civil Rights Law. American Journal of Sociology, 97(6): 1531-1576.

Edelman, L. B., Petterson, S., Chambliss, E., \& Erlanger, H. S. 1991. Legal Ambiguity and the Politics of Compliance: Affirmative Action Officers' Dilemma. Law \& Policy, 13(1): 73 97.

EFMD. 2013. EQUIS standards and criteria. Brussels: EFMD.

Elsbach, K. D., \& Sutton, R. I. 1992. Acquiring organizational legitimacy through illegitimate actions: a marriage of institutional and impression management theories. Academy of Management Journal, 35(4), 699-738. 
Espeland, W. N., \& Sauder, M. 2007. Rankings and Reactivity: How Public Measures Recreate Social Worlds. American Journal of Sociology, 113(1): 1-40.

Etzion, D., \& Ferraro, F. 2010. The Role of Analogy in the Institutionalization of Sustainability Reporting. Organization Science, 21(5): 1092-1107.

Evans, F. J., \& Weiss, E. J. 2008. Views on the importance of ethics in business education. In D. L. Swanson \& D. G. Fisher (Eds.) Toward assessing business ethics education: 43-66. Charlotte, NC: LAP.

Evans, J. M., Treviño, L. K., \& Weaver, G. R. 2006. Who's in the ethics driver's seat? Factors influencing ethics in the MBA curriculum. Academy of Management Learning and Education, 5: 278-293.

Fethke, G. C., \& Policano, A. J. 2013. Public no more universities: subsidy to self-reliance. Journal of Management Development, 32(5): 525-536.

Fiss, P. C., \& Zajac, E. J. 2006. The symbolic management of strategic change: sensegiving via framing and decoupling. Academy of Management Journal, 49(6): 1173-1193.

Forray, J. M., \& Leigh, J. S. A. 2012. A Primer on the Principles of Responsible Management Education: Intellectual Roots and Waves of Change. Journal of Management Education, 36(3): 295-309.

George, E., Chattopadhyay, P., Sitkin, S. B., \& Barden, J. 2006. Cognitive underpinnings of institutional persistence and change: A framing perspective. Academy of Management Review, 31: 347-365.

Giacalone, R. A., \& Wargo, D. T. 2009. The Roots of the Global Financial Crisis Are in Our Business Schools. Journal of Business Ethics Education, 6: 147-168.

Godemann, J., Haertle, J., Herzig, C., \& Moon, J. 2013. United Nations supported Principles for Responsible Management Education: purpose, progress and prospects. Journal of Cleaner Production (forthcoming).

Godemann, J., Herzig, C., Moon, J., \& Powell, A. 2011. Integrating Sustainability into Business Schools: Analysis of 100 UN PRME Sharing Information on Progress (SIP) reports. International Centre for Corporate Social Responsibility (ICCSR), Working Paper No. 582011. Nottingham: ICCSR.

Gross-Schaefer, A. 2010. Academic freedom: Moving away from the faculty-only paradigm. Journal of Legal Studies in Business, 16: 45-72.

Haack, P., Schoeneborn, D., \& Wickert, C. 2012. Talking the Talk, Moral Entrapment, Creeping Commitment? Exploring Narrative Dynamics in Corporate Responsibility Standardization. Organization Studies, 33(5-6): 815-845. 
Hansen, U., Moosmayer, D., Bode, M., \& Schrader, U. 2007. Values at work: Business professors' influence on corporate values. Berlin: Logos.

Hoffman, A. J. 1999. Institutional Evolution and Change: Environmentalism and the U.S. Chemical Industry, Academy of Management Journal, 42: 351-371.

Holland, K. 2009. Is it time to retrain B-Schools? Retrieved from http://www.nytimes.com/2009/03/15/business/15school.html (accessed 28 September 2013).

Kell, G., \& Haertle, J. 2011. UN Global Compact and Principles for Responsible Management Education: the next decades. Global Focus: The EFMD Business Magazine, 5(2): 14-16.

Klimek, J., \& Wenell, K. 2011. Ethics In Accounting: An Indispensable Course? Academy of Educational Leadership Journal, 15(4): 107-118.

Korn, M. 2011. Columbia's Business Dean on Disclosure, Leading, Ethics. Retrieved from: http://online.wsj.com/article/SB1000142405270230336580457642997425 6934518.html (accessed 27 October 2013).

Kurland, N.B., Michaud, K.E., Best, M., Wohldmann, E., Cox, H., Pontikis, K., \& Vasishth 2010. Overcoming Silos: The Role of an Interdisciplinary Course in Shaping a Sustainability Network. Academy of Management Learning \& Education, 9(3): 457-476.

MacLean, T. L., \& Behnam, M. 2010. The Dangers of Decoupling: the Relationship Between Compliance Programs, Legitimacy Perceptions, and Institutionalized Misconduct. Academy of Management Journal, 53: 1499-1520.

McLaughlin, M.W., \& Talbert, J.E. 2001. Professional Communities and the Work of High School Teaching. Chicago: University of Chicago Press.

Meyer, J. W., \& Rowan, B. 1977. Institutionalized Organizations: Formal Structure as Myth and Ceremony. American Journal of Sociology, 83(2): 340-363.

Murray, S. 2013. MBA Teaching Urged to Move Away From Primacy of Shareholder Value Model. Retrieved from: http://www.ft.com/intl/cms/s/2/e3 92f12c-adac-11e2-82b800144feabdc0.html\#axzz2j1YLpFa3 (accessed 29 October 2013).

Mortimer, K.P., \& Sathre, C. 2010. The Art and Politics of Academic Governance. Plymouth: Roman and Littlefield.

Navarro, P. 2008. The MBA Core Curricula of Top-Ranked U.S. Business Schools: A Study in Failure? Academy of Management Learning \& Education, 7(1): 108-123.

Net Impact 2009. New Leaders, New Perspectives: A Survey of MBA Student Opinions on the Relationship Between Business and Social/Environmental Issues. San Francisco: Net Impact. 
Nicholson, C. Y., \& DeMoss, M. 2009. Teaching ethics and social responsibility: An evaluation of undergraduate business education at the discipline level. Journal of Education for Business, 84: 213-218.

Oliver, C. 1991. Strategic Responses to Institutional Processes. Academy of Management Review, 16(1): 145-179.

Perry, M., \& Win, S. 2013. An Evaluation of PRME's Contribution to Responsibility in Higher Education. Journal of Corporate Citizenship, 49: 48-70.

Peters, K., \& Thomas, H. 2011. A sustainable model for business schools? Global Focus: The EFMD Business Magazine, 5(2): 24-27.

Pitt, L. F., Berthon, P., Spyropoulou, S., \& Page, M. J. 2006. How well are business schools managing their brands? A research note. Journal of General Management, 31(3): 1-10.

Principles for Responsible Management Education (PRME) (2013a). PRME - The Principles for Responsible Management Education. Available at: http://www.unprme.org (accessed 2 December 2013).

Principles for Responsible Management Education (PRME) (2013b). PRME Champions. Available at: http://www.unprme.org/working-groups/champions.php (accessed 28 October 2013).

Romero, E. J. 2008. AACSB accreditation: Addressing faculty concerns. Academy of Management Learning and Education, 7: 245-255.

Ruef, M., \& Scott, W. R. (1998). A Multidimensional Model of Organizational Legitimacy: Hospital Survival in Changing Institutional Environments. Administrative Science Quarterly, 43(4), 877-904.

Sambell, K., \& McDowell, L. 1998. The Construction of the Hidden Curriculum: messages and meanings in the assessment of student learning. Assessment \& Evaluation in Higher Education, 23(4): 391-402.

Samuelson, J. 2011. Graduating MBAs are ill equipped to lead firms in uncertain times. Retrieved from http://www.huffingtonpost.com/judith-samuelson/graduating-mbas-areilleq_b_861043.html (accessed 15 October 2013).

Searle, J. R. 1969. Speech Acts: An Essay in the Philosophy of Language. Cambridge: Cambridge University Press.

Scott, R. W. 1995. Institutions and Organizations. London: Sage.

Shrivastava, P. 2010. Pedagogy of Passion for Sustainability. Academy of Management Learning \& Education, 9(3): 443-455. 
Solitander, N., Fougere, M., Sobczak, A., \& Herlin, H. 2011. We Are the Champions: Organizational Learning and Change for Responsible Management Education. Journal of Management Education, 36(3): 337-363.

Starik, M., Rands, G., Marcus, A. A., \& Clark, T. S. 2010. In Search of Sustainability in Management Education. Academy of Management Learning \& Education, 9(3): 377-383.

Suchman, M. C. 1995. Managing Legitimacy: Strategic and Institutional Approaches. Academy of Management Review, 20(3): 571-610.

Swanson, D., \& Fisher, D. 2008. Business ethics education: If we don't know where we're going, any road will take us there. In D. L. Swanson \& D. G. Fisher (Eds.) Advancing business ethics education: 1-24. Charlotte, NC: IAP. Swanson.

Taylor, J. R., \& Cooren, F. 1997. What Makes Communication “Organizational”? How the Many Voices of a Collectivity Become the One Voice of an Organization, Journal of Pragmatics 27: 409-38.

Waddock, S., Rasche, A., Werhane, P., \& Unruh, G. 2011. The principles for responsible management education: Implications for implementation and assessment. In D. L. Swanson \& D. G. Fisher (Eds.), Toward assessing business ethics education: 13-28. Charlotte, NC: IAP.

Wedlin, L. 2007. The Role of Rankings in Codifying a Business School Template: Classifications, Diffusion and Mediated Isomorphism in Organizational Fields, European Management Review, 4: 24-39.

Weick, K. E. 1979. The Social Psychology of Organizing, 2nd ed. New York, NY: McGrawHill.

Westphal, J. D., \& Zajac, E. J. 2001. Decoupling Policy from Practice: The Case of Stock Repurchase Programs. Administrative Science Quarterly, 46(2): 202-228.

Westphal, J. D., \& Zajac, E. J. 1998. The Symbolic Management of Stockholders: Corporate Governance Reforms and Shareholder Reactions. Administrative Science Quarterly, 43(1): $127-153$.

Westphal, J. D., Gulati, R., \& Shortell, S. M. 1997. Customization or Conformity? An Institutional and Network Perspective on the Content and Consequences of TQM Adoption. Administrative Science Quarterly, 42(2): 366-394.

Wilson, D., \& McKiernan, P. 2011. Global Mimicry: Putting Strategic Choice Back on the Business School Agenda. British Journal of Management, 22(3): 457-469. 
Wu, Y.-C., Huang, S., Kuo, L., \& Wu, W.-H. 2010. Management Education for Sustainability: A Web-Based Content Analysis. Academy of Management Learning \& Education, 9(3): $520-531$.

Young, S., \& Nagpal, S. 2013. Meeting the growing demand for sustainability-focused management education: a case study of a PRME academic institution. Higher Education Research \& Development, 32(3): 493-506.

Zucker, L. G. 1987. Institutional Theories of Organization. Annual Review of Sociology, 13(1): 443-464. 